\title{
Impact of voluntary fortification and supplement use on dietary intakes of folate and status in an Irish adult population
}

\author{
S. M. Hopkins ${ }^{1}$, B. A. McNulty ${ }^{1}$, J. Walton ${ }^{2}$, A. Flynn ${ }^{2}$, A. M. Molloy ${ }^{3}$, J. M. Scott ${ }^{3}$, H. McNulty ${ }^{4}$, \\ A. P. Nugent ${ }^{1}$ and M. J. Gibney ${ }^{1}$ \\ ${ }^{1}$ UCD Institute of Food and Health, University College Dublin, Belfield, Dublin 4, ${ }^{2}$ School of Food and Nutritional \\ Sciences, University College Cork, Cork, ${ }^{3}$ School of Clinical Medicine, Trinity College, Dublin 2, ${ }^{4}$ Northern Ireland Centre \\ for Food and Health, University of Ulster, Coleraine, BT52 ISA, UK
}

Mandatory folic acid fortification in the US has significantly increased folic acid intakes and folate status in all subgroups of their population $^{(1)}$. Now concerns are growing regarding the possible adverse effects of these high intakes and status levels ${ }^{(2-3)}$. Ireland and the UK are examples of countries where a voluntary folic acid fortification policy exists but little is known about how this practice in addition to supplement use effects total folate intakes and status.

The aim of this study is to examine the impact of voluntary fortification and supplement use on total folate intakes and folate status in an Irish adult population. Participants who provided a 4-day food diary and a blood sample as part of the National Adult Nutrition Survey were included $(n=1126)$ in the analysis ${ }^{(4)}$. Natural folate and folic acid from fortified foods and supplements were determined for each food consumed. Participants were categorised into four consumption groups based on their source of folic acid intake. Red cell folate $(\mathrm{RCF})$ and serum folate (SF) were measured by microbiological assay.

\begin{tabular}{|c|c|c|c|c|c|}
\hline & Non-Consumers ${ }^{1}$ & $\begin{array}{l}\text { Fortified food (FF) } \\
\text { consumers }^{2}\end{array}$ & Supplement user $^{3}$ & $\begin{array}{l}\text { FF \& supplement } \\
\text { consumer }^{4}\end{array}$ & $P$ \\
\hline$n$ & 201 & 767 & 35 & 123 & \\
\hline Male:female (\%) & $48: 52$ & $52: 48$ & $43: 57$ & $43: 57$ & 0.169 \\
\hline Age & $45(31,55.5)^{*}$ & $42(28,55)$ & $38(26,58)$ & $38(27,52)$ & 0.273 \\
\hline \multicolumn{6}{|l|}{ Dietary intake $(\mu \mathrm{g})$} \\
\hline Natural folate & $206(160,295)$ & $223(176,284)$ & $239(177,310)$ & $246(185,309)$ & 0.983 \\
\hline Total folic acid & - & $69(32,142)^{\mathrm{a}}$ & $200(150,400)^{\mathrm{b}}$ & $287(220,438)^{\mathrm{b}}$ & $<0.001$ \\
\hline Total folate & $206(160,295)^{\mathrm{a}}$ & $311(239,427)^{\mathrm{b}}$ & $557(365,629)^{\mathrm{c}}$ & $582(431,746)^{\mathrm{c}}$ & $<0.001$ \\
\hline \multicolumn{6}{|l|}{ B vitamin status } \\
\hline Serum folate $(\mathrm{nmol} / \mathrm{l})$ & $17.0(12.3,24.3)^{\mathrm{a}}$ & $26.1(17.4,37.8)^{\mathrm{b}}$ & $30.2(22.3,46.4)^{\mathrm{bc}}$ & $44.9(29.2,68.6)^{\mathrm{c}}$ & $<0.001$ \\
\hline High SF $(>45.3 \mathrm{nmol} /) \%$ & $5.0^{\mathrm{a}}$ & $18.5^{\mathrm{b}}$ & $25.7^{\mathrm{b}}$ & $48.0^{\mathrm{c}}$ & $<0.001$ \\
\hline $\mathrm{RCF}(\mathrm{nmol} / \mathrm{l})$ & $702(538,936)^{\mathrm{a}}$ & $885(697,1194)^{\mathrm{b}}$ & $1000(804,1444)^{\mathrm{bc}}$ & $1159(828,1519)^{\mathrm{c}}$ & $<0.001$ \\
\hline Low RCF $(<453 \mathrm{nmol} / \mathrm{l}) \%$ & $10.4^{\mathrm{a}}$ & $5.6^{\mathrm{b}}$ & $0^{\mathrm{b}}$ & $1.6^{\mathrm{b}}$ & 0.003 \\
\hline
\end{tabular}

Total folate intakes, serum folate and RCF were significantly higher in folic acid consumers compared to non consumers. Supplement users had significantly higher folic acid intakes and folate status than those who consumed folic acid from fortified foods alone. Non consumers of folic acid had a significantly higher prevalence of low RCF and a lower prevalence of high serum folate than consumers. These results show an uneven distribution of folic acid intakes across population subgroups due to voluntary fortification and supplement use. Although the majority of the population may have a higher folate status associated with voluntary fortification and supplement use, non consumers of folic acid (18\%) may be at risk of suboptimal status. Furthermore, of potential concern is the high prevalence of high serum folate levels, which may have adverse consequences in terms of unmetabolised folic acid ${ }^{(2)}$.

This study was funded by the Irish Department of Agriculture, Fisheries and Food under the Food for Health Research Initiative (2007-2012).

1. Bailey RL, Dodd KW, Gahche JJ et al. (2010) Am J Clin Nutr 91, 231-237.

2. Morris MS, Jacques PF \& Rosenberg IH (2010) Am J Clin Nutr 91, 1733-1744.

3. Cole BF, Baron JA, Sandler RS et al. (2007) JAMA 297, 2351-2359.

4. Universities Nutrition Alliance (2011) The National Adult Nutrition Survey. http://www.iuna.net 